\title{
Some Aspects of Liquor Control in California
}

\author{
Dixwell L. Pierce*
}

$A_{\text {nomic and political problems, is both controversial and complex. It is }}^{\text {LCOHolic beverage control, involving as it does dificult social, eco- }}$ controversial because of the wide differences of opinion with respect to what should be done toward the solution of these problems. It is complex, in California particularly, because of the wide differences in the attitudes toward the liquor traffic that prevail in the several areas of our heterogeneous commonwealth, where the same law is applicable without any allowance for these differences. By mandate of the people, ${ }^{1}$ the State Board of Equalization has been given the administrative responsibility in this controversial and complex field of the law.

An attempt was made in the December, 1950, issue of California Law Review to survey the situation under the title The State Board of Equalization and Liquor Control. ${ }^{2}$ To a substantial extent this comment is oriented about what happened last year to a Mr. Charles W. Hawkins of San Joaquin County, familiarly mentioned in the Comment as "Charlie Hawkins." Oddly enough, Mr. Hawkins was not a licensee under the Alcoholic Beverage Control Act, although the author of the Comment assumed that he was. Possibly the sensational aspects of the Hawkins affair were too great a temptation for one who seemed more concerned with these than with the legal problems that are postulated under the California Constitution and statutes in the field of the regulation of the manufacture, sale and consumption of alcoholic beverages.

Perhaps because of a preoccupation with the news interest of Mr. Hawkins' behavior and that of the liquor control officers who accomplished his arrest for selling wine without a license, the author of the Comment neglected to verify the facts as they pertain to the administrative activity of the Board, as well as to complete the legal research that would have been essential to have produced an accurate commentary on the subject. Were it not for the circumstance that readers of the Law Review, accustomed to regard its contents as carefully written and documented, would be prone to accept these statements as facts and the review of the authorities as reasonably complete, no substantial harm would result.

* Secretary, California State Board of Equalization.

[Editorial note: This article is presented for whatever light it may shed upon the complicated problems of hiquor control in California. The Board of Editors takes no side in the controversy between Mr. Pierce and the author of the student comment which is being criticized, recognizing that contributors on complex political subjects are entitled to bave personal opinions. Whether the errors and omissions pointed out by Mr. Pierce destroy the validity of the Comment is for the reader to decide].

\footnotetext{
1 CAL. Const. Art. XX, $\$ 22$.

238 CALJF. L. REv. 875 (1950).
} 
When the readers make these assumptions with respect to the Comment there is, however, considerable misunderstanding created in their minds as to how the Board actually operates in the difficult field of liquor control. This is most certainly not in the public interest because an agency given such responsibility inevitably must be prepared to meet warranted criticism. It is entitled to all of the public confidence that it may enjoy on the basis of its actual record without being subjected to unwarranted attack that tends to discredit its activities by innuendo. For this reason, and no other, this brief correction of some of the misstatements and omissions in the Comment has been prepared.

To facilitate orderly examination of these inaccuracies, they are grouped in the following categories: (1) fair trade, (2) hearing officers, (3) law enforcement problems, and (4) sales tax administration. These subjects will be considered in the order of their enumeration.

1. Fair Trade

Contrary to the statement in the Comment, ${ }^{3}$ it is untrue that the Unfair Trade Practices Act ${ }^{4}$ is one of the basic laws governing the liquor control activities of the State Board of Equalization. The Board has no duties connected with that statute, which is distinct from the Fair Trade Act. ${ }^{6}$ In the fair trade field the Board is governed by the Alcoholic Beverage Control $\mathrm{Act}^{6}$ and by judicial pronouncements relating to the Fair Trade Act. The error of assuming otherwise is significant for the reason that the author of the Comment has oriented his discussion relating to the Board's activities in the price field upon the supposition that the Board proceeds under the Unfair Trade Practices Act and could use the injunctive process there contemplated.

People v. Centr-O-Mart, ${ }^{7}$ upon which the commentator relies, ${ }^{8}$ is in no way applicable to what the Board is expected to do in the fair trade field. Contrary to his suggestion, there are no situations in which the Board is authorized to use an injunction to enforce its revocation or suspension orders. A licensee affected by such an order has the right to commence a mandate action to prevent the order from becoming final. ${ }^{9}$ In the instant case, the order of the Board revoking the license of Mr. Hawkins' wife (he had no license) was the subject of such a proceeding in the San Joaquin County Superior Court. This order was upheld on December 7, 1950.10 The jury trial of $\mathrm{Mr}$. Hawkins mentioned in the Comment ${ }^{11}$ involved the criminal offense of selling wine without a license at 2725 Waterloo Road, San Joaquin County, in violation of the Alcoholic Beverage Control Act ${ }^{32}$

\footnotetext{
3 Id. at 876 .

4 Car. Bus. \& Prof. Code $\$ \$ 17000-17101$.

- Cal. Bus. \& Prof. Code $\$ \$ 16900-16905$.

6 2 Cal. Gen. Stats., Act 3796 (Deering 1944).

7 34 Cal. 2d 702, 214 P. 2d 378 (1950).

838 CaIIF. L. REv. 891.

9 Cal. Govt. Code $\$ 11523$; Cal. Code Crv. Proc. $\$ 1094.5$.

$10 \mathrm{CCH}$ Cal. Liquor Control Service $\| 9040$.

1138 CaITF. L. REv. 890, 891.

122 Cal. Gen. Stats., Act 3796, § 3.
} 
after the license for the premises had been revoked. This revocation order had been made following a hearing under the Administrative Procedure $\mathrm{Act}^{\mathrm{13}}$ at which it was established that there was a deliberate sale of beer at these premises below the fair trade price in violation of the Board's rule $^{14}$ and of the Act. ${ }^{15}$ These are the facts in the Hawkins incident, although what is said in the Comment ${ }^{16}$ would leave the reader with an entirely different impression of what occurred.

Apparently the commentator labors under confusion as to whether the fair trade violation which occurred at the Waterloo Road premises was with respect to mandatory or optional fair trade. ${ }^{15}$ The cases which he cites are those that have failed to uphold mandatory fair trade.$^{18}$ Although there are authorities holding the opposite view, none is mentioned in the Comment. ${ }^{10}$ It is significant also that the Illinois and New York cases cited ${ }^{20}$ were decided on other grounds and did not turn on the fair trade issue. What is even more significant is that the sale of beer for which Mrs. Hawkins' license was revoked was in violation of voluntary fair trade.

A New Jersey liquor control regnlation closely analogous to that here involved was upheld in that jurisdiction. There are other decisions upholding optional or voluntary fair trade such as was applicable in the Hawkins case. ${ }^{21}$ Apparently all of these authorities escaped the attention of the commentator, as it seems inconceivable that their omission would have been purposeful.

Hinting that fair trade violations of this type are rampant and that Mrs. Hawkins was the victim of some simster plot, the commentator raises a query as to a possible defense by a licensee in a fair trade case in such a way as to create an impression that no authoritative answer is readily to be found. ${ }^{22}$ Actually, the question which he leaves unanswered has been judicially determined. ${ }^{23}$

It is not the purpose of what is said here to attempt a defense of price controls. It may well be, as suggested by the commentator, that they are distasteful to consumers generally. ${ }^{24}$ The violation in the Hawkins case was with respect to a legislative enactment. ${ }^{25}$ It is difficult to perceive why

\footnotetext{
13 CaI. Govt. Code $\S \S 11500$ et seq.

14 CAL. AdMm. CodE, Tit. 4, c. $1, \S 99$.

152 Car. Gen. Stats., Act 3796, § 55.6.

1638 CALIF. L. REv. 890, 891.

1T Id. at 888,889 .

18 Ibid.

19 Reeves v. Simons, 289 Ky. 793, 160 S. W. 2 d 149 (1942); see note 21 infra.

20 Illinois Liquor Control Commission v. Chicago's Last Liquor Store, 403 Ill. 578, 88 N. E. 2d 15 (1950); Levine v. O'Connell, 88 N.Y.S. 2d 672 (1949).

21 Gaine v. Burnett, 122 N. J. L. 39, 4 A. 2d 37 (1939); Old Dearborn Distributing Co. v. Seagram Distillers Corporation, 299 U.S. 183 (1936); Max Factor and Co. v. Kunsman, 5 Cal. 2d 446, 55 P. 2d 177, aff'd, 299 U.S. 198 (1936).

2238 CALIF. L. REv. 890.

${ }^{23}$ See cases collected in Note, 125 A.L. R. 1335, 1359 (1940); see also Note, 86 L. Ed. at

2438 CALIF. L. REv. 891.

252 CaL. Gen. Stats., Act 3796, § 55.6.
} 1420,1438 (1942). 
it should be to the discredit of the Board to endeavor to do its administrative duty in conformity with the law, although it seems obvious that that is the viewpoint of the author of the Comment. If he desires to argue either that (a) there should be no such price regulation, or (b), if there is, it should be enforced by some other agency than the licensing authority, that is certainly his privilege. It is inappropriate, however, for him to attempt to cast discredit upon the administrative agency merely because he does not like the law which it is directed to enforce.

\section{Hearing Officers}

It is indicated incorrectly in the Comment that the Board's hearing officers consult with other agencies to gain more information regarding an accused licensee and that there have been examples of hearing officers helping with the investigation of cases before other hearing officers of the Board. ${ }^{26}$ It is true that hearing officers have occasion to receive in evidence information from other law enforcement agencies im such matters, but when this is done the data are always placed in the record with full knowledge of the applicant or licensee, who is given opportunity to make such objection, explanation or answer as he may deem appropriate. Since enactment of the Administrative Procedure Act in 1945 approximately 10,000 cases have been heard by the Board's hearing officers. In only one of these has a hearing officer ever presented a case before another hearing officer. This certainly does not support the observations made by the author of the Comment.

By innuendo the commentator seeks to discredit the hearings conducted by the Board officers through attributing to these hearings "a unique flavor," by purporting to discuss "some of the questionable legal aspects of Board adjudication" and by referring to the use of full-time hearing officers as a "dubious factor." 27 Nothing tangible is offered in support of these ill-advised expressions which reflect on the author rather than on those at whom they are directed. If the commentator. is aware of any questionable practices at which he hints with such delicacy he owes it to himself and his readers to be precise and specific. Otherwise, he should refrain from sly insinuations regarding honorable members of the California Bar. Such tactics do him no credit.

The practice of using full-time hearing officers has been approved for sound reasons by the Judicial Council of California. ${ }^{28}$ It has been recognized with approval both by federal and state lawmakers. ${ }^{29}$ If the author disagrees with those who thus approve of the assignment of full-time hearing officers to an agency such as the State Board of Equalization that is his privilege, but he has scarcely presented an unbiased comment on the subject when he omits all reference to these authorities.

26 38 CALIF. L. REv. 883.

27 Ibid.

28 Tenth Brennial Report, Judiclal Council of Calfrornia 15, 36.

295 U.S. C. A. \$1010; CaI. Govt. CodE § 11502. See discussion in Wong Yang Sung v. McGrath, 339 U.S. 33 (1950). 


\section{Law Enforcement Problems}

In what purports to be a discussion of the problems involved in the suspension or revocation of alcoholic beverage licenses for offenses other than those under the Alcoholic Beverage Control Act the Comment omits reference to the basic statutory provision on this point. ${ }^{30}$ The author merely mentions related violations which he indicates include gambling, prostitution and narcotic traffic. ${ }^{31}$

Section 40 of the Act provides that the Board may suspend or revoke a license when the licensee violates the Act or violates "any other penal provisions of law of this State prohibiting or regulating the sale," etc., of alcoholic beverages or the adulteration or misbranding of such beverages. Examples of these related offenses are those pertaining to the use of " $\mathrm{B}$ " girls, ${ }^{32}$ to the sale of liquor to Indians ${ }^{33}$ and to the refilling of distilled spirits bottles. ${ }^{34}$ In addition, Section 40 also authorizes the Board to suspend or revoke the license of one who has been convicted of a crime involving moral turpitude. Obviously, this does not include convictions of agents or employees of the licensee; nor does it authorize the Board to presume a licensee guilty of such a crime until his conviction.

The nub of the law enforcement problem as involved in the Alcoholic Beverage Control Act is found in Section 40. Section 38d of that Act, granting peace-officer powers to employees of the Board, significantly is limited to those that must be utilized in the enforcement of the Act. Although a discussion was begun on this question in the Comment, ${ }^{35}$ there was no attempt to develop the matter, even though the point is vital. Obviously, in cases where the Board employees do not have peace-officer powers usually the arrests must be made and the evidence developed by local peace officers. Under Section 58 of the Alcoholic Beverage Control Act, the Board often has suspended or revoked licenses of persons who permit their licensed premises to be used as disorderly houses for purposes of prostitution or illicit narcotic traffic.

The purpose of Section 58 may be understood only in the light of similar laws relating to disorderly houses ${ }^{36}$ and the decisions that pertain thereto. ${ }^{37}$ The possibility of enlarging the concept of what constitutes a disorderly house under California law is intriguing. Discussion of this subject might be appropriate in connection with proposed legislation. It is hardly appropriate when directed toward the efforts of an administrative agency with the inference that, through some enlargement of the hitherto prevailing concept, the law might be made to cover a wider area than has heretofore been indicated by the lawmakers or courts of California.

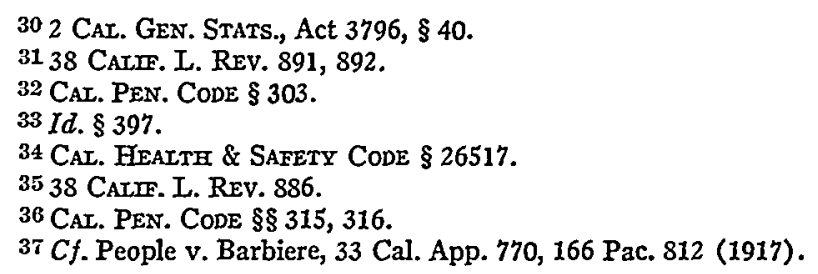




\section{Sales Tax Administration}

There is indication in the Comment that the Board attempted to retaliate against Mr. Hawkins because of his resistance to arrest by subjecting him to excessive audit under the Sales and Use Tax Law. ${ }^{38}$ This assertion is utterly without foundation.

It is said in a footnote: "Other departments of the Board seem to have taken an active interest in Hawkins' affairs; he claims to have undergone three tax audits so far this year (1950)."39 What the author neglected to explain was that the business at 2725 Waterloo Road was conducted by a corporation named "Don Quick Stores" whose affairs were managed by Mr. Hawkins; that in the corporate return of gross receipts taxable under the Sales and Use Tax Law for the first quarter of 1950 an item of deduction was entered with the cryptic explanation that this was the value of merchandise confiscated by the Board; that in addition to Don Quick Stores, Mr. Hawkins had interests in other retail enterprises known as "Tinker Stores" and "Bigg \& Littel Stores," both located near the 2725 Waterloo Road premises.

Naturally, the type of deduction claimed on the Don Quick Stores sales tax return was questioned when the report was received at the capital and the headquarters staff requested a field audit. Experience had shown that Mr. and Mrs. Hawkms had become confused in the past as to what business had been done by her individually and what in a corporate capacity. In the light of this, the sales tax auditors decided to audit all three accounts in 1950 when the request for the Don Quick Stores audit was received from Sacramento. If the author of the Comment had taken the trouble to ascertain the facts it seems doubtful that he would have inferred any element of retaliation in the audits that Mr. Hawkins has "undergone" recently.

If the commentator believes that the administration of the regulatory laws pertaining to alcoholic beverages and of the law pertaining to the taxation of retail sales of tangible personal property might be improved through assigning these responsibilities to separate agencies, no objection may be made legitimately to his expression of that belief. If he seeks to support his conviction by examples of administrative activity calculated to demonstrate that the administration of either law suffers because they are under the jurisdiction of the same agency, that is his recogmized privilege. Those who serve the public must learn to accept criticism. It is submitted, however, that nothing that is said in the Comment with respect to the alleged "retaliation" is supported in fact. The only real discredit attaching to this part of the Comment is that which inures to the commentator for making this insinuation without securing the facts.

\section{Conclusion}

No one at all familiar with problems of liquor control in California would be so optimistic as to make the assertion derided by the author at

38 Cax. Rev. \& Tax Code, Div. 2, Part 1.

3938 CaxIF. L. REV. 886. 
the close of his Comment-that California liquor control represents "the best of all possible systems." In a penetrating foreword written by Dr. Luther Gulick ${ }^{40}$ to After Repeal ${ }^{41}$ there is this observation:

Even age-old problems, like the control of liquor, take on new difficulty with the social, economic and mechanical changes that have come in the last twenty-five years. The weakening of family, church and community discipline; new machinery, chemistry and the automobile; more cash wages and dependency; and the speed-up of monotony, have combined to make of the liquor problem a new task in every modern nation. ${ }^{42}$

\section{Dr. Gulick concludes:}

In short, it may be said that there are few major problems of public admimistration which do not emerge in striking fashion in connection with the governmental effort to control the consumption of alcohol. ${ }^{43}$

In another text ${ }^{44}$ reviewing systems of liquor control in America, there is this pertinent comment:

In a delicate field, involving divergent standards and appetites, our main approach has been by way of the police.... On no other theory can be based an explanation of the intricate legal patchwork which has constituted our chief defense against the abuse of alcohol .... As Dean Pound of Harvard has pointed out, there must be something more than the abstract content of the legal precept to move human beings to act. Certainly the only standard which the law has any hope of enforcing is the standard prevailing in the community as a whole .... The test of the law's validity is the strength of the social reaction which supports it. ${ }^{45}$

When one attempts to deal with such a dynamic problem as liquor control in California, where our population has doubled in the fifteen years that we have had our present regulatory provisions, there is no occasion for innuendo directed at those to whom this tremendous responsibility has been assigned. Anyone who is in a position to suggest a better system or a better administration than we now have is certainly entitled to respectful attention. He should rejoice at the opportunity of making his suggestions to as intelligent a group of readers as those who peruse the California Law Review. He should not abuse this privilege by purporting to give "facts" that are not facts and by attributing to the administrative authorities sinister motives of which he has no proof. Such tactics may serve only to bring confusion into an area where the public interest requires clear thinking. If given the facts, the Bar of California is in a position to contribute in no small part to the clarity of thought on this important subject.

\footnotetext{
40 President, American Institute of Public Administration.

41 LEONARD V. HARRISON AND ELIZABETH LANE (Harper \& Brothers 1936).

42 Id. vii.

43 Id. xix.

44 Ratarond B. Fosdick and Albert L. Scott, Toward Liquor Control (Harper \& Brothers 1933).

$45 I d$. at $6,7,8$.
} 
Perhaps we would do well to follow the suggestion of a lawyer of the nineteenth century: ${ }^{46}$

In a contemplative fashion,

And a tranquil frame of mind,

Free from every kind of passion,

Some solution let us find.

Let us grasp the situation,

Solve the complicated plot-

Quiet, calm deliberation

Disentangles every knot.

46 Sir William S. Gilbert, in his lyrics for The Gondoliers (Gilbert and Sullivan). 